\title{
PHOTOCHEMISTRY OF INTERMOLECULAR C-H BOND ACTIVATION REACTIONS
}

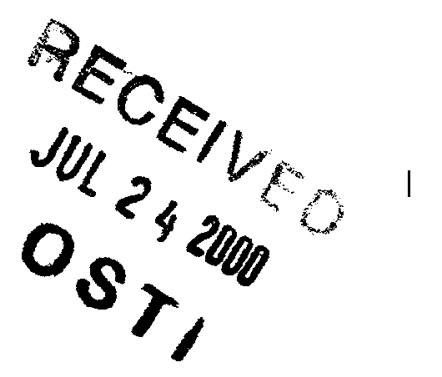

Final Report on Grant DE-FG02-89ER14039

Office of Basic Energy Sciences

Division of Chemical Sciences

Office of Energy Research

U.S. Department of Energy

Professor Alistair J. Lees

Department of Chemistry

State University of New York

at Binghamton

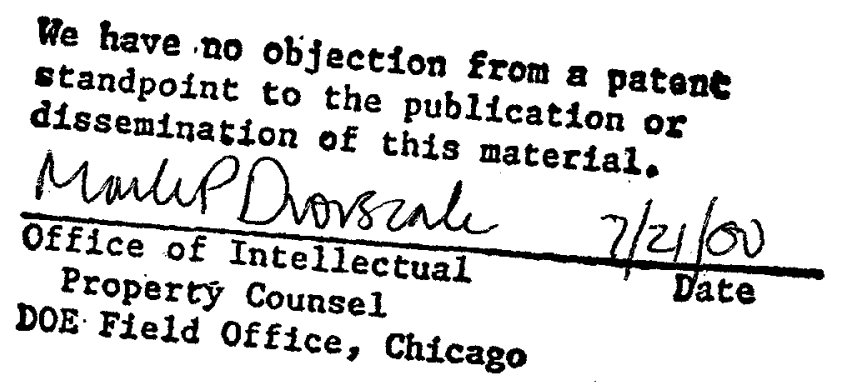




\section{DISCLAIMER}

This report was prepared as an account of work sponsored by an agency of the United States Government. Neither the United States Government nor any agency thereof, nor any of their employees, make any warranty, express or implied, or assumes any legal liability or responsibility for the accuracy, completeness, or usefulness of any information, apparatus, product, or process disclosed, or represents that its use would not infringe privately owned rights. Reference herein to any specific commercial product, process, or service by trade name, trademark, manufacturer, or otherwise does not necessarily constitute or imply its endorsement, recommendation, or favoring by the United States Government or any agency thereof. The views and opinions of authors expressed herein do not necessarily state or reflect those of the United States Government or any agency thereof. 


\section{DISCLAIMER}

Portions of this document may be illegible in electronic image products. Images are produced from the best available original document. 


\section{SCIENTIFIC AND TECHNICAL PROGRESS}

\section{A. Project Period}

June 15, 1989 - March 14, 2000

\section{B. Specific Project Objectives}

The major goal of this project has been to gain photophysical and photochemical insight as to why transition-metal organometallic systems facilitate intermolecular $\mathrm{C}-\mathrm{H}$ bond activation reactions with various hydrocarbon substrates. The emphasis of the research has been to determine the details of the solution photochemistry involved in $\mathrm{C}-\mathrm{H}$ activation via quantitative measurements of these processes. Specifically, this has included:

(a) characterizing the electronically-excited states of the metal complexes that are responsible for the photochemistry that leads to intermolecular $\mathrm{C}-\mathrm{H}$ bond activation;

(b) determining the absolute photochemical quantum efficiencies of $\mathrm{C}-\mathrm{H}$ bond activation reactions for these metal complexes in different hydrocarbon solutions and at various excitation wavelengths;

(c) measuring the photophysical properties of these organometallic complexes at both ambient and low temperatures;

(d) deriving the nature of the photochemical mechanisms taking place in solution, including the identity and reactivity of the primary photoproducts and other key intermediates produced in the reaction pathway; and

(e) determining the optimum conditions required to perform photochemicallyinduced $\mathrm{C}-\mathrm{H}$ bond activation reactions.

\section{Summary of Major Research Activities}

An integral part of the research carried out has been the development of a kinetic procedure for determining absolute photochemical quantum efficiencies of intermolecular $\mathrm{C}-\mathrm{H}$ bond activation reactions in fluid solution (1). The method has enabled us to acquire the first available quantitative data for photochemical transformations in which there are several overlapping absorbances at the excitation wavelength. Thus, this procedure accounts for the substantial effects of inner filter absorptions and the fact that these are changing during the course of the reaction.

These quantitative measurements of the photochemistry have enabled us to measure and provide a valuable comparison of the $\mathrm{C}-\mathrm{H}$ bond activation efficiency for several organometallic systems known to undergo intermolecular $\mathrm{C}-\mathrm{H}$ bond activation $(2,3)$. The effects of varying excitation wavelength and changing the hydrocarbon substrate have been quantitatively determined. Efforts have been directed at characterizing the nature of the electronically-excited states and their photophysical deactivation processes, including analysis of electronic absorption spectra and measuring low-temperature luminescence spectra.

Importantly, the quantitative photochemistry results have enabled time-resolved spectroscopic measurements (4) and work in low- temperature liquified rare gas solutions (5) to be performed successfully on these organometallic systems. Significantly, our 
quantitative results have made it possible to elucidate a detailed picture of all the pathways occurring in the photochemical mechanisms of these important $\mathrm{C}-\mathrm{H}$ activating compounds.

\section{Overview of Project Findings}

Substantial progress has been made on characterizing the solution photochemistry of rhodium carbonyl complexes that facilitate intermolecular $\mathrm{C}-\mathrm{H}$ bond activation of hydrocarbon substrates. This has included an extensive investigation of $\mathrm{CpRh}(\mathrm{CO})_{2}$ and $\mathrm{Cp} * \mathrm{Rh}(\mathrm{CO})_{2}\left(\mathrm{Cp}=\eta^{3}-\mathrm{C}_{5} \mathrm{H}_{5} ; \mathrm{Cp}^{*}=\eta^{5}-\mathrm{C}_{5} \mathrm{Me}_{5}\right)$ complexes (2). Significantly, it was found that the quantum efficiencies for phosphine $\left(\mathrm{PR}_{3}\right)$ and arsine (AsR $\left.{ }_{3}\right)$ ligand substitution in these complexes are dependent on the entering ligand concentration and the nature of the entering ligand, and we have deduced that there are two ligand field (LF) excited states with quite distinct reactivities in the photochemical mechanism. Clearly, two different reaction intermediates are implicated in the solution photochemistry of $\mathrm{CpRh}(\mathrm{CO})_{2}$ and $\mathrm{Cp} * \mathrm{Rh}(\mathrm{CO})_{2}$. The photoreactivity was also studied in triethylsilane $\left(\mathrm{Et}_{3} \mathrm{SiH}\right)$ solution and contrastingly, it has been found that the quantum efficiencies are independent of entering $\mathrm{Et}_{3} \mathrm{SiH}$ ligand concentration at high $\left[\mathrm{Et}_{3} \mathrm{SiH}\right]$, but show a dependence on $\left[\mathrm{Et}_{3} \mathrm{SiH}\right]$ at low values (see Figures 1 and 2). A kinetic analysis has been applied to these photochemical efficiencies results in order to elucidate the solution mechanism (2e).

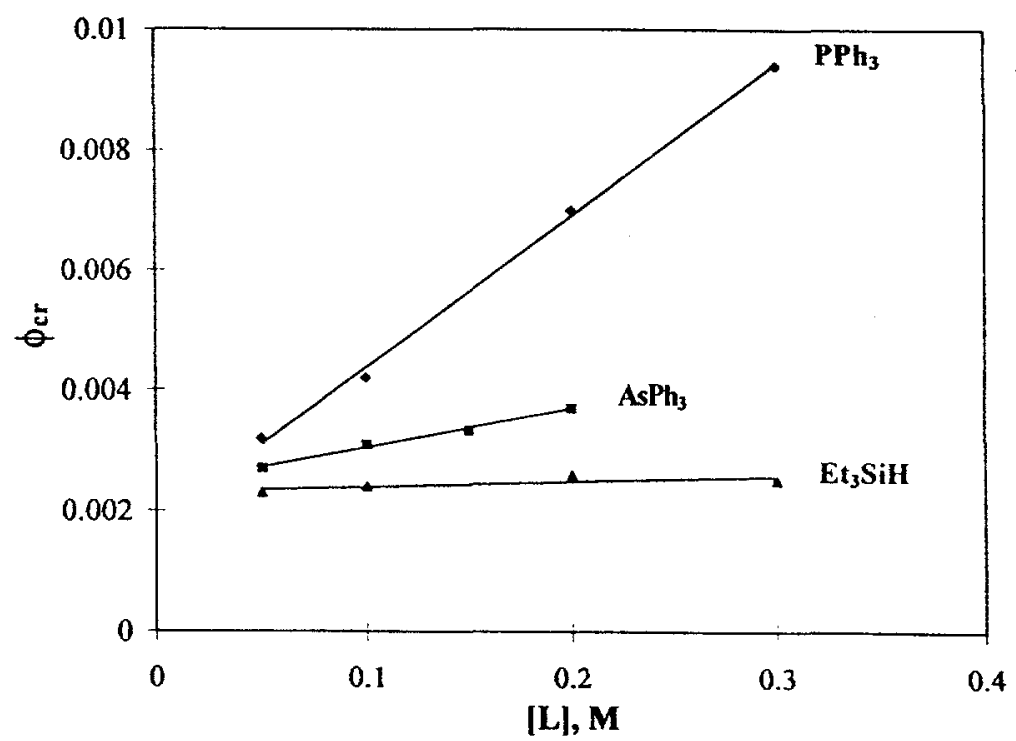

Figure 1. Plots of photochemical quantum efficiency $\left(\phi_{\mathrm{Cr}}\right)$ versus scavenging ligand [L] concentration for the 458-nm ligand substitution $\left(\mathrm{L}=\mathrm{PPh}_{3}\right.$ and $\left.\mathrm{AsPh}_{3}\right)$ and $\mathrm{Si}-\mathrm{H}$ bond activation reactions of $\mathrm{CpRh}(\mathrm{CO})_{2}$ in deoxygenated decalin at 293 K.

The photochemistry can be understood by invoking different pathways following excitation at short and long wavelengths. Upon 313-nm excitation (short wavelength) of $\mathrm{CpRh}(\mathrm{CO})_{2}$ in hydrocarbon $(\mathrm{RH})$ solution an upper energy LF state is reached and the photoreactivity is characterized by facile $\mathrm{CO}$ dissociation and high quantum efficiency $\left(\phi_{\mathrm{cr}}\right.$ $>0.1$ ) for both ligand substitution and $\mathrm{C}-\mathrm{H} / \mathrm{Si}-\mathrm{H}$ bond activation reactions. 


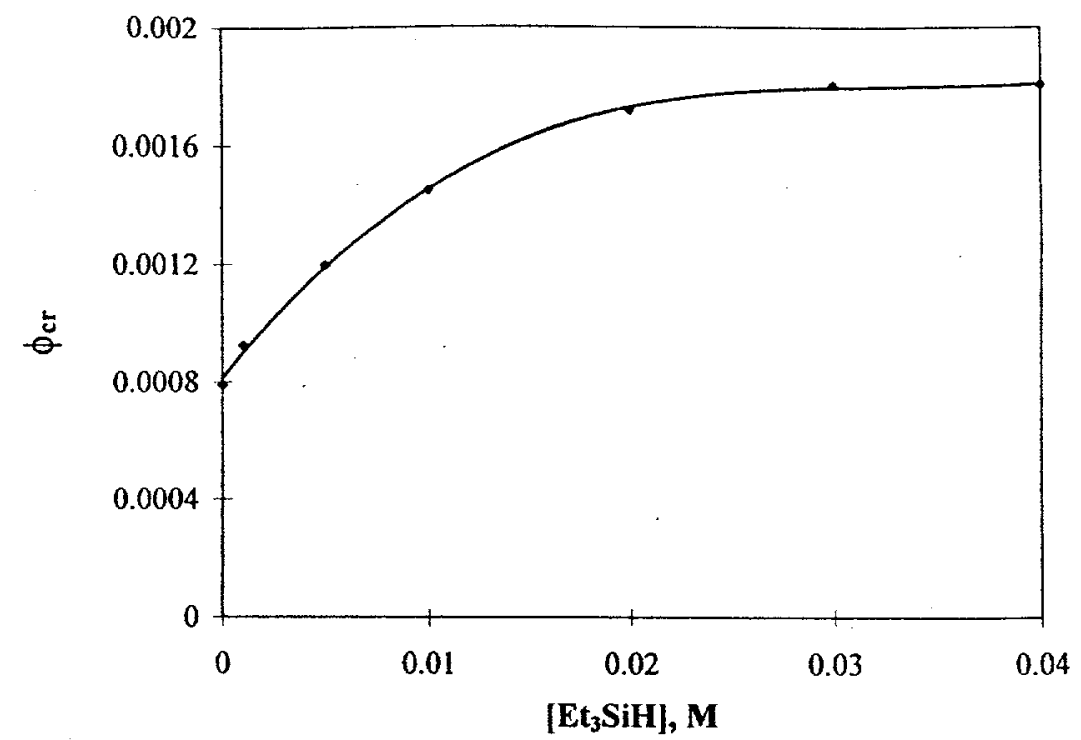

Figure 2. Plots of photochemical quantum efficiency $\left(\phi_{\mathrm{cr}}\right)$ versus $\mathrm{Et}_{3} \mathrm{SiH}$ concentration for the 458-nm Si-H bond activation reaction of $\mathrm{CpRh}(\mathrm{CO})_{2}$ in deoxygenated decalin at $293 \mathrm{~K}$.

The photoefficiency data are entirely consistent with the primary photoproduct being the hydrocarbon solvated $\mathrm{CpRh}(\mathrm{CO})$ monocarbonyl species $(2 \mathrm{~b}, \mathrm{e}, \mathrm{f}, 6)$, which is able to react in a variety of ways depending on the reaction conditions (see Scheme 1). However, it should be noted that the alkyl hydride complex, $\mathrm{CpRh}(\mathrm{CO})(\mathrm{R}) \mathrm{H}$, is also unstable in this particular system and it has been identified as a reaction intermediate in flash photolysis; this transient species has a lifetime on the order of milliseconds in the absence of a scavenging ligand and it undergoes reductive elimination to form $[\mathrm{CpRh}(\mu-$ $\mathrm{CO})]_{2}$ and subsequently the trans- $\mathrm{Cp}_{2} \mathrm{Rh}_{2}(\mathrm{CO})_{3}$ product (4b). The $\mathrm{CpRh}(\mathrm{CO}) \mathrm{PR}_{3}$ and $\mathrm{CpRh}(\mathrm{CO})\left(\mathrm{SiEt}_{3}\right) \mathrm{H}$ species are stable and have been isolated $(2 \mathrm{~b}, \mathrm{e})$.

Scheme 1

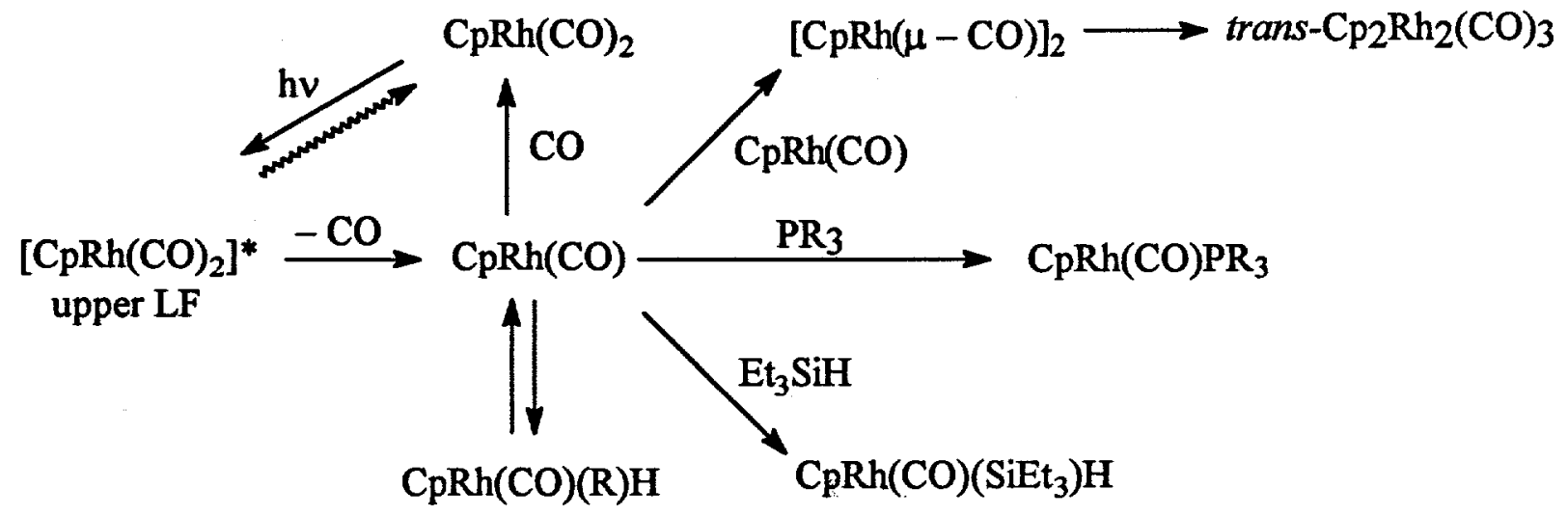

$\mathrm{CpRh}(\mathrm{CO})$ in understood to be solvated by hydrocarbon $(\mathrm{RH})$ 
In sharp contrast, the 458-nm excitation (long wavelength) predominantly populates a lower-energy LF excited state which is characterized by an inefficient $\left(\phi_{\mathrm{cr}} \sim\right.$ $10^{-3}$ ) photosubstitution reaction (see Scheme 2). A ring slippage $\left(\eta^{5} \rightarrow \eta^{3}\right)$ mechanism involving the cyclopentadienyl ligand (7) has been invoked on the basis of the $\phi_{\mathrm{cr}}$ results, which are influenced by the nature and concentration of the entering $\mathrm{PR}_{3}$ ligand. In such a mechanism, the competition of a back ring-slip process effectively lowers the reaction quantum efficiency for photosubstitution. The $\left(\eta^{3}-\mathrm{Cp}\right) \mathrm{Rh}(\mathrm{CO})_{2}$ intermediate is once again considered to be solvated (2e). The photoreactivity at long wavelength, therefore, appears to be similar to the thermal substitutional chemistry of this system (8).

Scheme 2

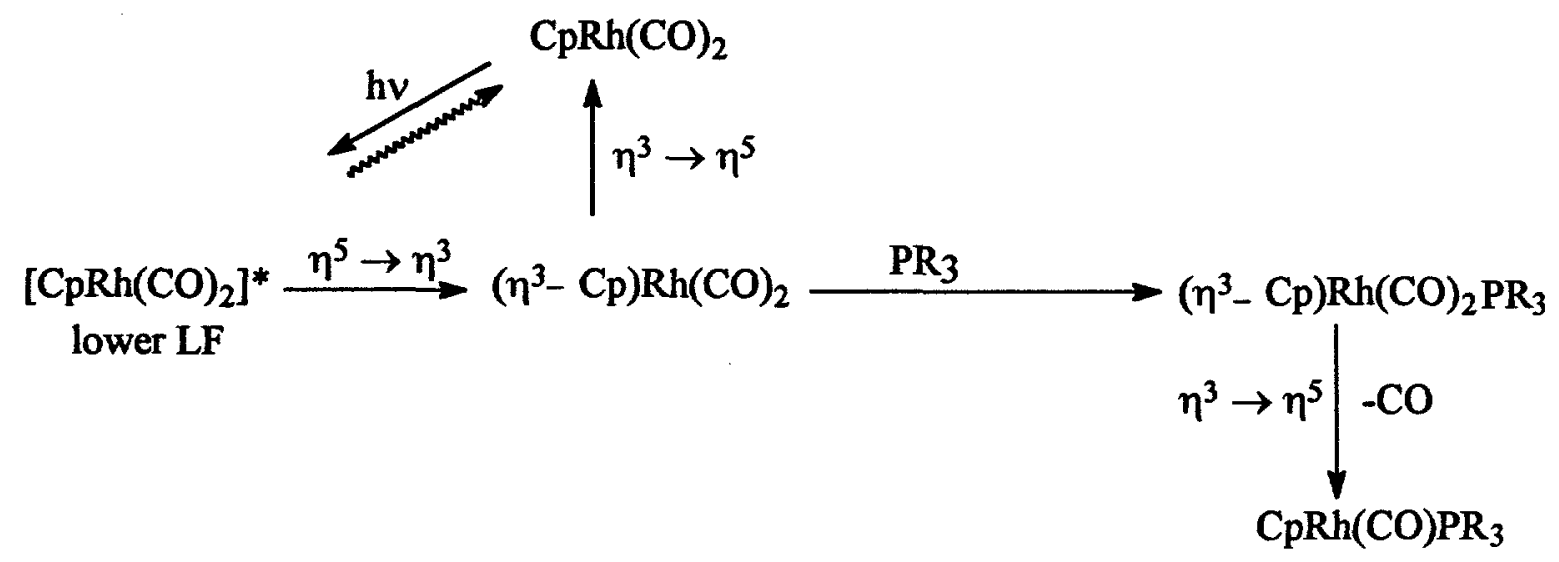

$\left(\eta^{3}-\mathrm{Cp}\right) \mathrm{Rh}(\mathrm{CO})_{2}$ is understood to be solvated by hydrocarbon $(\mathrm{RH})$

A key feature of the kinetic analysis of the quantum efficiencies is that both of the LF excited states are extremely short lived and the primary photoproducts are immediately solvated prior to ligand scavenging or $\mathrm{C}-\mathrm{H} / \mathrm{Si}-\mathrm{H}$ bond activation (2e). Indeed, CO dissociative reactions typically take place on the timescale of a few picoseconds $(9,10)$ and we have found that the complexes themselves are non-luminescent at $77 \mathrm{~K}(2 \mathrm{~d})$, consistent with extremely rapid dissociations from LF states (11).

Much attention has also been paid to understanding the photochemistry of the analogous $\left(\mathrm{HBPz}^{\prime}{ }_{3}\right) \mathrm{Rh}(\mathrm{CO})_{2}\left(\mathrm{Pz}^{\prime}=3,5\right.$-dimethylolpyrazolyl) system following the initial report of intermolecular C-H activation (12). Recently, we have studied the thermal and photochemical pathways in alkane solutions at room temperature (3). The thermal mechanism has been characterized to involve rapid $\eta^{3} \leftrightarrow \eta^{2}$ ligand interconversions and indeed the protonated complex, $\left[\left\{\eta^{2}-\left(\mathrm{HBPz}^{\prime}{ }_{3}\right) \mathrm{Rh}(\mathrm{CO})_{2}\left(\mathrm{Pz}^{\prime} \mathrm{H}\right)\right\} \mathrm{Rh}(\mathrm{CO})_{2}\right] \mathrm{BF}_{4}$, is readily formed on addition of $\mathrm{HBF}_{4} \cdot \mathrm{OEt}$ to $\left(\mathrm{HBPz}_{3}^{\prime}\right) \mathrm{Rh}(\mathrm{CO})_{2}$. The photochemistry is exceptionally clean in each of the alkanes studied and conversion of the parent complex to form the hydrido photoproduct takes place completely for each hydrocarbon (see eq 1).

$$
\left(\mathrm{HBPz}_{3}{ }_{3}\right) \mathrm{Rh}(\mathrm{CO})_{2} \underset{\mathrm{RH}}{\stackrel{\mathrm{h} v}{\longrightarrow}}\left(\mathrm{HBPz}^{\prime}{ }_{3}\right) \mathrm{Rh}(\mathrm{CO})(\mathrm{R}) \mathrm{H}+\mathrm{CO}
$$


Absolute photochemical quantum efficiencies $\left(\phi_{\mathrm{CH}}\right)$ have been determined for these reactions and these illustrate that the $\mathrm{C}-\mathrm{H}$ activation process is strongly dependent on the exciting wavelength. Very effective conversion $\left(\phi_{\mathrm{CH}}=0.31-0.34\right)$ is attained upon excitation at 313 or $366 \mathrm{~nm}$ (short wavelength) and inefficient conversion $\left(\phi_{\mathrm{CH}}=0.010\right.$ 0.011 ) is observed upon photolysis at $458 \mathrm{~nm}$ (long wavelength). The experimental observations have been again interpreted in terms of different photochemical mechanisms originating from two low-lying LF states, in which the long-wavelength photochemistry and the thermal chemistry of $\left(\mathrm{HBPz}_{3}{ }_{3}\right) \mathrm{Rh}(\mathrm{CO})_{2}$ are associated with the initial formation of a solvated $\left(\eta^{2}-\mathrm{HBPz}_{3}{ }_{3}\right) \mathrm{Rh}(\mathrm{CO})_{2}$ intermediate that is unable to undergo $\mathrm{C}-\mathrm{H}$ bond activation. The reduction in quantum efficiency is then brought about by an effective ligand rechelation $\left(\eta^{2} \rightarrow \eta^{3}\right)$ process of the $\eta^{2}$-intermediate. Significantly, we have prepared the analogous square planar $\left(\mathrm{H}_{2} \mathrm{BPz}_{2}\right) \mathrm{Rh}(\mathrm{CO})_{2}$ complex (see below) and have found that it is reactive towards phosphine ligands but not $\mathrm{R}-\mathrm{H}$ in room-temperature solution, supporting the conclusion that the above $\eta^{2}$-species is unable to $\mathrm{C}-\mathrm{H}$ activate hydrocarbons (3b). In contrast, the short-wavelength photochemisty is attributed to proceed via an extremely short-lived monocarbonyl $\left(\mathrm{HBPz}^{\prime}{ }_{3}\right) \mathrm{Rh}(\mathrm{CO})$ complex that facilitates efficient $\mathrm{C}-\mathrm{H}$ bond activation. Recent femtosecond flash photolysis measurements have confirmed that the primary photoproduct formed on UV excitation is indeed a monocarbonyl fragment which is produced and solvated within $10 \mathrm{ps}$ (10h). Moreover, it has been determined that $\left(\mathrm{HBPz}_{3}^{\prime}\right) \mathrm{Rh}(\mathrm{CO})_{2}$ is not luminescent in 2Me-THF or EPA glasses at $77 \mathrm{~K}(3 \mathrm{a}, \mathrm{b})$, consistent with LF levels which are highly dissociative and short lived (11). Scheme 3 summarizes the postulated photochemical routes for the various excitation wavelengths.

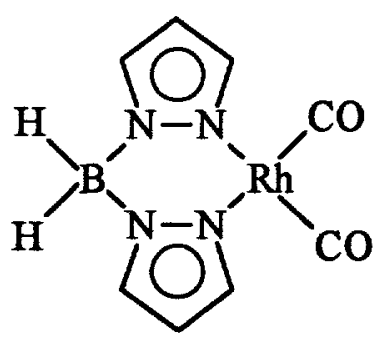

A comparison of the photophysical processes of the $\mathrm{CpRh}(\mathrm{CO})_{2}$ and $\left(\mathrm{HBPz}_{3}^{\prime}\right) \mathrm{Rh}(\mathrm{CO})_{2}$ systems illustrates a number of significant features. As noted above, both molecules are believed to undergo extremely fast ligand dissociation reactions from LF excited states and, in each case, two different mechanisms involving $\mathrm{CO}$ dissociation and ligand interconversions are determined $(2 \mathrm{~d}, \mathrm{f})$. For $\mathrm{CpRh}(\mathrm{CO})_{2}$ the electronic absorption spectrum indeed reveals two LF bands, but for $\left(\mathrm{HBPz}_{3}{ }_{3}\right) \mathrm{Rh}(\mathrm{CO})_{2}$ only a broad LF absorption is observed so the assignment of two excited states must be derived from the photochemical behavior. In both cases the $\mathrm{C}-\mathrm{H}$ activation photochemistry clearly arises by rapid $\mathrm{CO}$ dissociation and yet, interestingly, the observed $\phi_{\mathrm{CH}}$ values are not dependent on added $\mathrm{CO}$ concentration $(2,3)$. Apparently, once the $\left(\mathrm{HBPz}^{\prime}{ }_{3}\right) \mathrm{Rh}(\mathrm{CO})$ primary photoproduct is formed (and rapidly solvated) it is not able to recombine with CO to any significant extent and it is subsequently converted completely to the $\mathrm{C}-\mathrm{H}$ activated product. Hence, in these Rh systems the photoefficiencies of the C-H activation process are not influenced by mechanistic events occurring after the formation of the 
Scheme 3

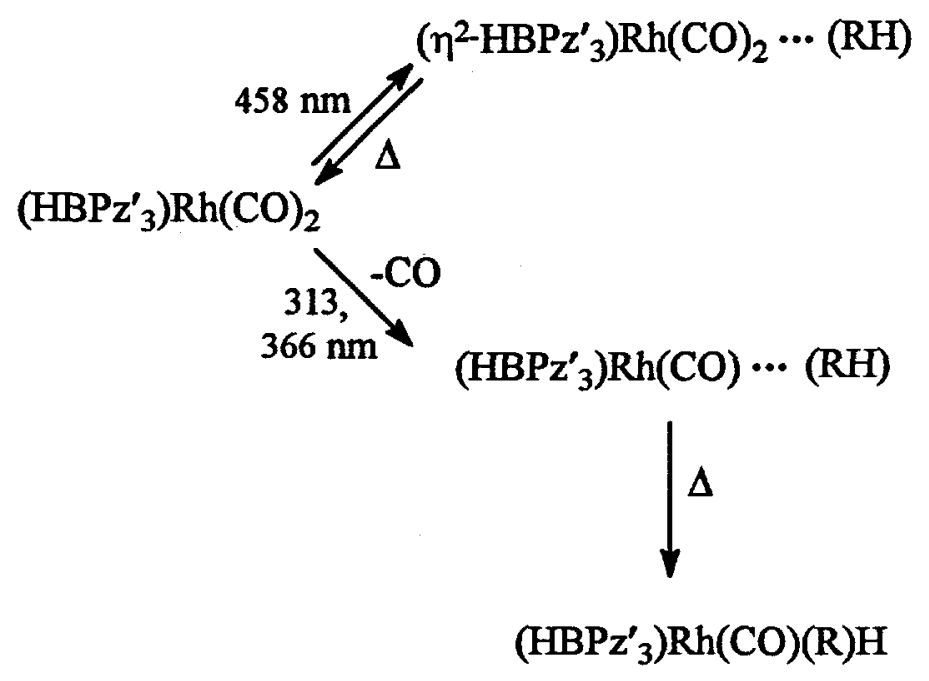

primary photoproduct. Instead, the photoefficiencies appear to be determined solely by photophysical effects and, specifically, by the branching ratio of the dissociative and nondissociative pathways from the upper LF excited state.

Photoreactivity measurements on $\mathrm{CpRh}(\mathrm{CO})_{2}$ and $\left(\mathrm{HBPz}_{3}^{\prime}\right) \mathrm{Rh}(\mathrm{CO})_{2}$ have recently been carried out in several hydrocarbon solutions at room temperature (2e,3c). Results obtained for the intermolecular $\mathrm{Si}-\mathrm{H}$ bond activation reaction in the $\mathrm{CpRh}(\mathrm{CO})_{2}$ system reveal a distinct solvent effect (see Table 1). At any particular exciting wavelength the photoefficiency values are similar across a range of alkanes but are substantially reduced in aromatic solvents, even though it has also been determined that the aryl hydrido

Table 1. Photochemical Quantum Efficiencies $\left(\phi_{\mathrm{cr}}\right)$ as a Function of Excitation Wavelength for the Intermolecular $\mathrm{Si}-\mathrm{H}$ Bond Activation Reaction of $\mathrm{CpRh}(\mathrm{CO})_{2}$ in Various Solvents at $293 \mathrm{~K}^{\mathrm{a}}$

\begin{tabular}{lccc}
\hline & & $\lambda_{\text {ex }}, \mathrm{nm}$ & \\
\cline { 2 - 4 } solvent & & & \\
& 313 & 366 & 458 \\
\hline -hexane & 0.29 & 0.078 & 0.0032 \\
$n$-heptane & 0.29 & 0.060 & 0.0023 \\
$n$-octane & 0.22 & 0.081 & 0.0026 \\
isooctane & 0.31 & 0.089 & 0.0026 \\
decalin & 0.15 & 0.060 & 0.0024 \\
benzene & 0.035 & 0.017 & 0.00074 \\
d6-benzene & 0.054 & 0.024 & 0.00071 \\
toluene & 0.036 & 0.0074 & 0.00082 \\
$p$-xylene & 0.061 & 0.033 & 0.0014 \\
\hline
\end{tabular}

aValues were determined in triplicate and were reproducible to within $\pm 10 \%$

bSolutions contain $0.05 \mathrm{M} \mathrm{Et}_{3} \mathrm{SiH}$ 
photoproducts are found to be more thermodynamically stable than the alkyl hydrido species. Similar observations have been made for the $\left(\mathrm{HBPz}^{\prime}{ }_{3}\right) \mathrm{Rh}(\mathrm{CO})_{2}$ system (3c). In each case, the differences in $\phi_{C H}$ have been rationalized in terms of solvent effects on the nonradiative relaxation rates from the complexes, and more specifically from the upper LF levels responsible for the $\mathrm{CO}$ dissociative photochemistry $(2 \mathrm{e}, 3 \mathrm{c})$. Hence, it can be concluded that the main influence on the photoefficiency of $\mathrm{C}-\mathrm{H}$ activation is not the breaking of the C-H bond itself. Again, the solvent results clearly indicate that it is the photophysical deactivation mechanism which predominately affects the quantitative $\mathrm{C}-\mathrm{H}$ activation chemistry.

A comparison of the electronic properties and photochemical reactivity efficiencies for a series of rhodium dicarbonyl complexes with the general formula $\mathrm{XRh}(\mathrm{CO})_{2}$, where $\mathrm{X}=\mathrm{Cp}\left(\eta^{5}-\mathrm{C}_{5} \mathrm{H}_{5}\right), \mathrm{Cp}^{\prime}\left(\eta^{5}-\mathrm{C}_{5} \mathrm{H}_{4} \mathrm{Me}\right), \mathrm{Cp}^{\prime \prime}\left(\eta^{5}-\mathrm{C}_{5} \mathrm{HMe}_{4}\right), \mathrm{Cp}^{*}\left(\eta^{5}-\mathrm{C}_{5} \mathrm{Me}_{5}\right)$, ind $\left(\eta^{3}-\mathrm{C}_{9} \mathrm{H}_{7}\right)$ and acac $\left(\mathrm{C}_{5} \mathrm{H}_{7} \mathrm{O}_{2}\right)$ (see below), has been carried out (13). The photochemical reactions of these molecules have been studied under a variety of experimental conditions, where binucleation, intermolecular $\mathrm{Si}-\mathrm{H}$ and $\mathrm{C}-\mathrm{H}$ bond activation, and ligand substitution processes occur. Modifications of the unique ligand in this system enables the photoefficiency of the $\mathrm{CO}$ dissociation reaction to be substantially changed. The absolute reaction quantum efficiencies $\left(\phi_{\mathrm{cr}}\right)$ are markedly different and strongly wavelength dependent for each of the molecules studied (see Table 2). The values of $\phi_{\mathrm{cr}}$ decrease in the order $\mathrm{CpRh}(\mathrm{CO})_{2}>\mathrm{Cp}^{\prime} \mathrm{Rh}(\mathrm{CO})_{2}>\mathrm{Cp}^{*} \mathrm{Rh}(\mathrm{CO})_{2}>>(\mathrm{acac}) \mathrm{Rh}(\mathrm{CO})_{2}>$ (ind) $\mathrm{Rh}(\mathrm{CO})_{2}$ and vary by over three orders of magnitude depending on the complex chosen and the excitation wavelength employed.
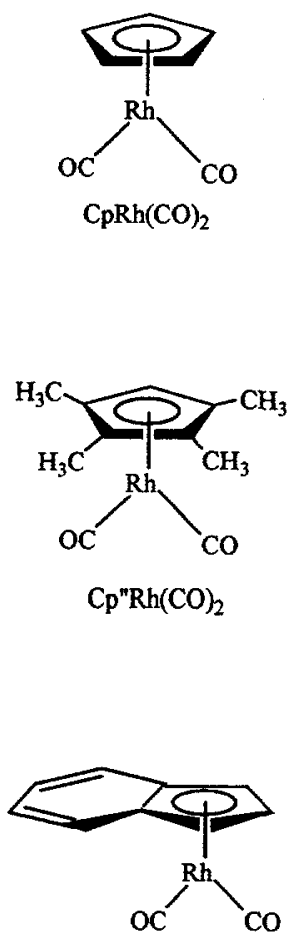

(ind) $\mathrm{Rh}(\mathrm{CO})_{2}$
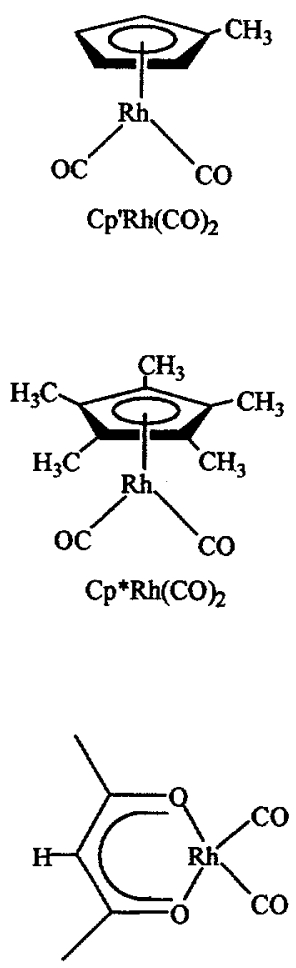

(acac)Rh(CO) 
Table 2. Photochemical Quantum Efficiencies $\left(\phi_{\mathrm{cr}}\right)$ for Conversion of $\mathrm{XRh}(\mathrm{CO})_{2}$ to their Corresponding Photoproducts at $293 \mathrm{~K}^{\mathrm{a}, \mathrm{b}}$

\begin{tabular}{|c|c|c|c|}
\hline \multirow[b]{2}{*}{ reaction products } & \multicolumn{3}{|c|}{$\phi_{\text {ar }}$} \\
\hline & $\lambda_{\mathrm{ex}}=313 \mathrm{~nm}$ & $\lambda_{\text {ex }}=366 \mathrm{~nm}$ & $\lambda_{\text {ex }}=458 \mathrm{~nm}$ \\
\hline $\mathrm{Cp}_{2} \mathrm{Rh}_{2}(\mathrm{CO})_{3}$ & 0.30 & 0.078 & \\
\hline $\mathrm{CpRh}(\mathrm{CO})\left(\mathrm{SiEt}_{3}\right) \mathrm{H}$ & 0.30 & 0.078 & 0.0032 \\
\hline CpRh(CO)cy & 0.30 & 0.078 & \\
\hline $\mathrm{Cp} p^{\prime} \mathrm{Rh}(\mathrm{CO})\left(\mathrm{SiEt}_{3}\right) \mathrm{H}$ & & & 0.0023 \\
\hline $\mathrm{Cp}^{*}{ }_{2} \mathrm{Rh}_{2}(\mathrm{CO})_{3}$ & 0.15 & 0.033 & \\
\hline $\mathrm{Cp} * \mathrm{Rh}(\mathrm{CO})\left(\mathrm{SiEt}_{3}\right) \mathrm{H}$ & 0.15 & 0.032 & 0.00017 \\
\hline $\mathrm{Cp} * \mathrm{Rh}(\mathrm{CO}) \mathrm{cy}$ & 0.15 & 0.034 & \\
\hline (ind) ${ }_{2} R h_{2}(\mathrm{CO})_{3}$ & 0.019 & 0.0084 & \\
\hline (ind)Rh(CO)cy & 0.018 & 0.0074 & \\
\hline$(\mathrm{acac})_{2} \mathrm{Rh}_{2}(\mathrm{CO})_{3}$ & 0.042 & 0.0082 & \\
\hline$(\mathrm{acac}) \mathrm{Rh}(\mathrm{CO}) \mathrm{cy}$ & 0.041 & 0.0083 & \\
\hline
\end{tabular}

All values are accurate to $\pm 10 \%$.

Concentrations of entering ligand are $0.05 \mathrm{M}$ in each case.

Several processes appear to strongly influence the photochemical reactivity of these $\mathrm{XRh}(\mathrm{CO})_{2}$ derivatives. On higher-energy excitation the carbonyl dissociation mechanism is predominant and this is characterized by high reaction quantum efficiencies and supported by the ample spectroscopic evidence noted above. However, in all the complexes studied here, there is a distinct reduction in photochemical efficiencies upon excitation at longer wavelengths, suggesting that a different reaction pathway takes place here. The drop in photoefficiency is understood to be associated with the different nature of the reaction intermediates occurring on excitation into the lower-energy absorption bands of these complexes. As noted above, for the $\mathrm{CpRh}(\mathrm{CO})_{2}$ complex this has been assigned to the presence of a ring slippage $\left(\eta^{5} \rightarrow \eta^{3}\right)$ mechanism occurring at lower-energy excitation. A similar argument is put forward for the methylated cyclopentadienyl derivatives, but the reduction in $\phi_{\mathrm{cr}}$ over the whole wavelength manifold studied is thought to be due to other factors that lead to enhanced nonradiative deactivation of the excited state, including increased vibrational deactivation and the possibility of intramolecular agostic interactions involving a methyl group (see Scheme 4). For the (ind) $R h(C O)_{2}$ complex, a ring-slippage intermediate, along with the possibility of an intramolecular $\eta^{2}$ interaction occurring in the formation of the slipped $\left(\eta^{3}\right.$-ind) $\mathrm{Rh}(\mathrm{CO})_{2}$ species (see Scheme 5), may also contribute to the quantitative photochemical observations. Finally, the quantitative photochemistry of ( $\mathrm{acac}) \mathrm{Rh}(\mathrm{CO})_{2}$ is rationalized with the incorporation of a dechelation/rechelation pathway occurring at long-wavelength excitation (see Scheme 6). 


\section{Scheme 4}
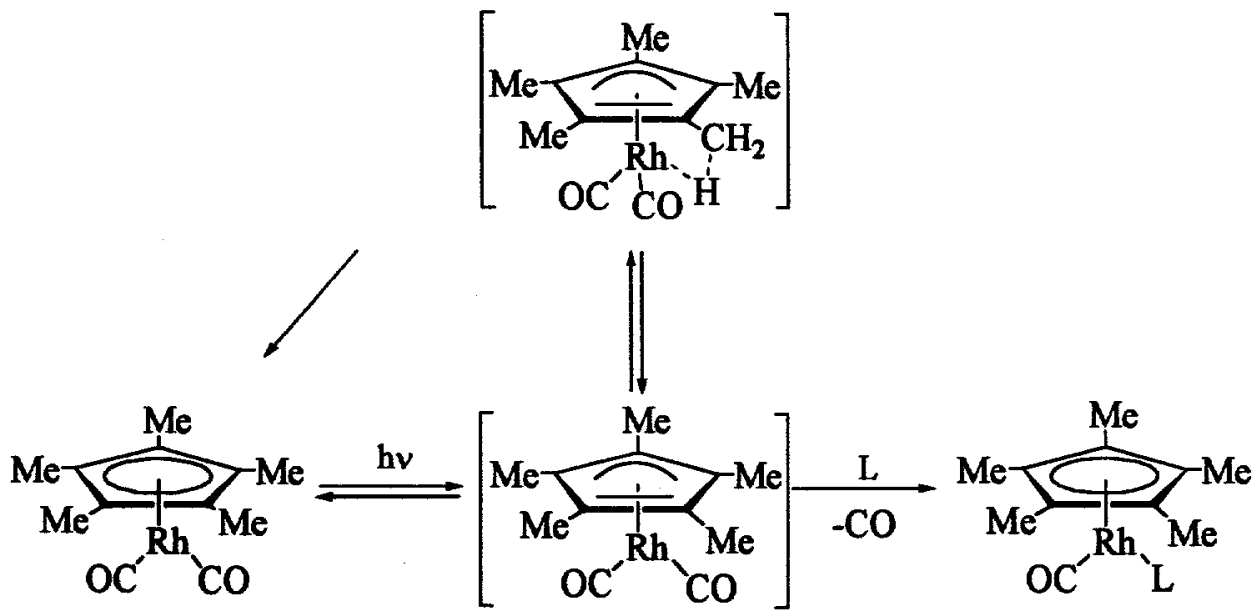

Scheme 5
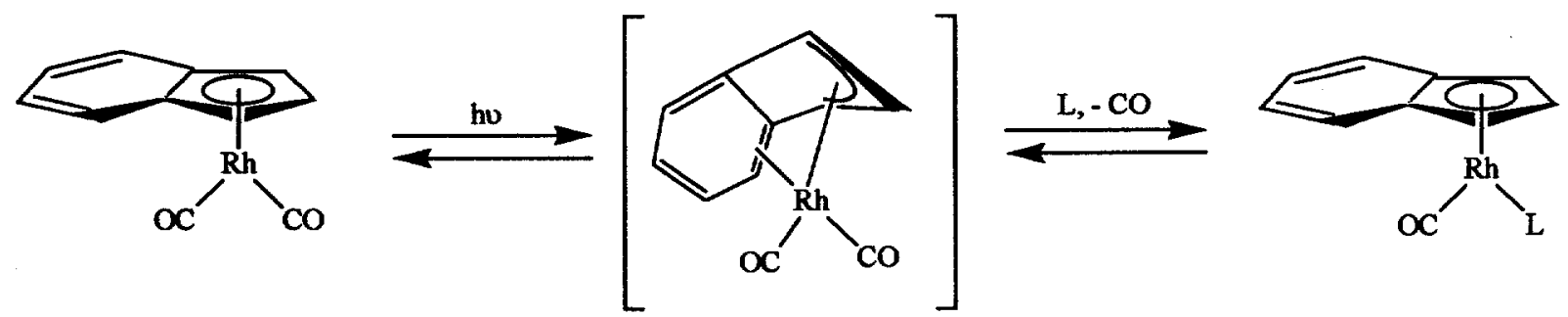

Scheme 6

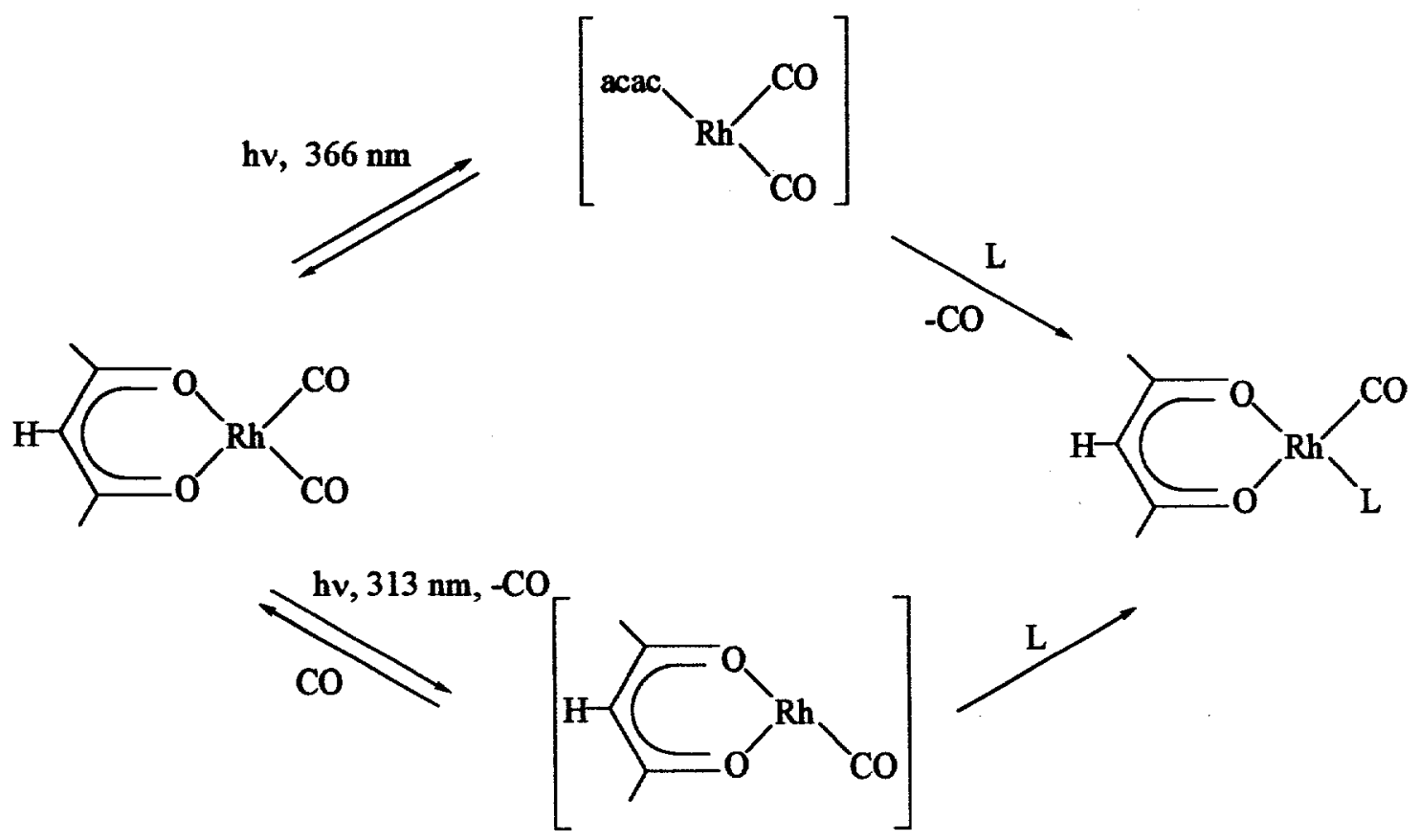


In related work, we have also explored the quantitative photoreactivity of some metal cluster complexes. Metal clusters present new avenues for activation and catalysis and, yet, our knowledge of the photochemistry of such complexes is rather limited. The photoisomerization of face-capping benzene triosmium clusters have recently been studied as a model for arene activation (14), so we have recently investigated the photochemical decarbonylation reaction arising from triosmium cluster complexes containing 2mercaptopyridine ligands (15). In our study, we determined that the photochemistry is exceptionally clean and involves the nitrogen of the mercaptopyridine ligand replacing a carbonyl ligand on the third osmium atom of the thiolate-bridged triangle. Quantitative measurements of the reactivity have been obtained. This work follows our earlier investigation of the photochemistry of high-nuclearity Os-Hg clusters (16).

The excited-state properties of several other organometallic complexes have also been investigated. Recently, we have studied the luminescence of W(CO) 4 (4-Me-phen) (4-Me-phen $=1,10$-phenanthroline) in room-temperature and low-temperature glassy solutions and in acrylate thin films (17). This system exhibits dual emission bands from triplet-centered metal-to-ligand charge transfer $\left({ }^{3} \mathrm{MLCT}\right)$ excited states and the lower energy band has been found to intensify and undergo a substantial blue shift as the acrylate polymerizes. The changes in luminescence properties have been associated with an intriguing rigidochromic effect affecting the lowest ${ }^{3} \mathrm{MLCT}$ excited state (17). The organometallic complex, fac-ClRe $(\mathrm{CO})_{3}$ (4,7- $\mathrm{Ph}_{2}$-phen) $\left(4,7-\mathrm{Ph}_{2}\right.$-phen = 4,7-diphenyl-1,10phenanthroline) has also been found to be a good spectroscopic probe for monitoring polymerization of aromatic cyanate ester monomers (18). The luminescence rigidochromic effect has been characterized for other organometallic complexes and we have demonstrated that these molecules are excellent spectroscopic probes of polymerization in both thermosetting and photoinitiating polymer systems (19).

In a related study the photophysical properties of the organometallic complex, $\mathrm{W}(\mathrm{CO})_{4}(\mathrm{en})(\mathrm{en}=$ ethylenediamine), have also been investigated. This complex is one of the few organometallic complexes that clearly exhibits both singlet and triplet lowest energy ligand field (LF) excited states in the absorption spectrum (20). It, therefore, presented an excellent opportunity to study the wavelength-dependent behavior of photosubstitutional processes in detail and to compare these results to the wavelengthdependent $\mathrm{C}-\mathrm{H}$ bond activation efficiencies that we determined in the $\mathrm{CpRh}(\mathrm{CO})_{2}$ and $\left(\mathrm{HBPz}_{3}{ }_{3}\right) \mathrm{Rh}(\mathrm{CO})_{2}$ systems. Quantitative results for the photochemistry of $\mathrm{W}(\mathrm{CO})_{4}(\mathrm{en})$ have been obtained and, importantly, they reveal unequivocally that the singlet and triplet LF excited states undergo quite separate dissociative pathways. The photoreactivity from the lowest-lying triplet state has been determined to proceed with a significantly reduced photoefficiency compared to be corresponding singlet level.

The quantitative photochemistry of $\mathrm{CpFe}(\mathrm{CO})_{2} \mathrm{I}$ in room-temperature solution has also been measured at several excitation wavelengths. The photoreactivity observed at long wavelength is exceptionally interesting as it has been shown to involve heterolytic cleavage of iodide from the metal center (21). We have found that this photochemistry is cleanest and most efficient at wavelengths longer than $600 \mathrm{~nm}$ and that excitation in this region provides a new way of effecting Fe-I dissociation in the $\mathrm{CpFe}(\mathrm{CO})_{2} \mathrm{I}$ complex. This work is significant because it facilitates an improved synthetic pathway to azaferrocene.

Recently, we have begun to study the photochemistry of [ $\mathrm{CpFe}$ (arene)]X (arene = benzene, toluene, napthalene, pyrene; $\mathrm{X}=\mathrm{PF}_{6}, \mathrm{BF}_{4}, \mathrm{SbF}_{6}, \mathrm{AsF}_{6}, \mathrm{CF}_{3} \mathrm{SO}_{3}$ complexes) (22). 
This system is an effective cationic photoinitiator for the polymerization of epoxy resins. Our studies have been again directed at determining the quantitative photochemistry with a view to learn about the mechanism of photoinitiation in solution at several excitation wavelengths. The mechanism of the photoreaction is understood to involve an initial arene slippage step. The photoefficiency results have revealed that the system exhibits a strong excitation wavelength dependence and that the photochemistry does not occur solely from the lowest-lying LF triplet excited state $(22 \mathrm{~b}, \mathrm{c})$, as previously thought.

Finally, we have begun to explore new avenues for organometallic photochemistry. A series of novel trinuclear metal complexes containing fac-(diimine) $\operatorname{Re}^{\mathrm{I}}(\mathrm{CO})_{3}$ chromophores and a stilbene-like bridging ligand have been synthesized and they exhibit photoswitchable luminescence in $\mathrm{CH}_{3} \mathrm{CN}$ arising from photoinduced intramolecular energy transfer from the $f a c$-(diimine) $\operatorname{Re}(\mathrm{CO})_{3}$ chromophores to the bridging ligand (23). Additionally, two luminescent triangle and square complexes have been prepared by selfassembly reactions of $\mathrm{XRe}(\mathrm{CO})_{5}$ and the corresponding bis-monodentate ligands (see Scheme 7). The structures of these molecules have been confirmed by a variety of techniques including NMR spectroscopy, $\mathrm{IR}$ spectroscopy, $\mathrm{FAB}^{+}$mass spectrometry and elemental analysis (24). Similarly, a series of heterometallic square complexes have been prepared by self-assembly between $\mathrm{BrRe}(\mathrm{CO})_{3}$ and (pyterpy $)_{2} \mathrm{M}\left(\mathrm{PF}_{6}\right)_{2}$, where $\mathrm{M}=\mathrm{Fe}, \mathrm{Ru}$ or Os (see Scheme 8). The luminescence and host-guest chemistry of these complexes have also been investigated (25). Our rapid progress in this area has stimulated an extensive study of the luminescence, electrochemical, and host-guest properties of a series of squares, triangles and dimers involving Re(I) chromophores (26). It is apparent that the cavities inside these molecules may act as catalytic microreactors and that these systems may also serve as molecular sensors. In this regard, we have recently synthesized a new luminescent rhenium (I) polypyridyl-based complex that acts as a receptor for a variety of inorganic anions (27). This receptor molecule (see Scheme 9) shows high affinities for halides, cyanide and acetate anions with binding constants as high as $10^{4}-10^{5} \mathrm{M}^{-1}$ and a detection limit as low as $10^{-8} \mathrm{M}$ in $\mathrm{CH}_{2} \mathrm{Cl}_{2}$ solution. One of the most exciting aspects of this system is that the molecule is such a simple, yet highly sensitive, luminescent metalcomplex receptor.

\section{Scheme 7}
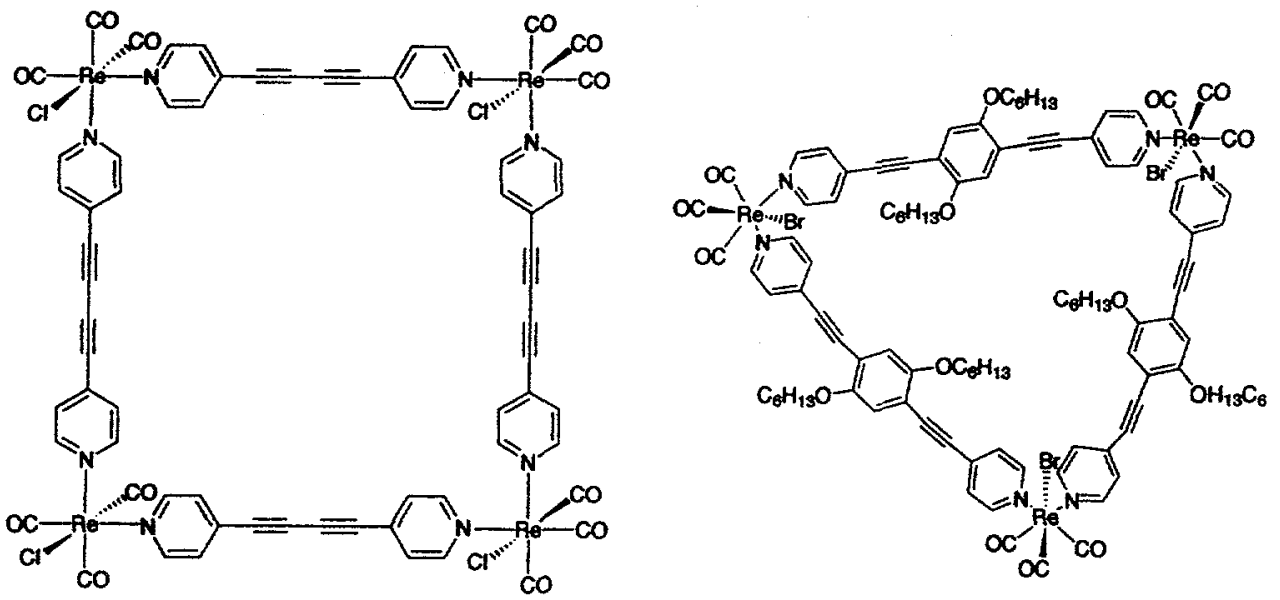
Scheme 8

$$
\begin{aligned}
& \mathrm{BrRe}(\mathrm{CO})_{5}+\mathrm{L} \underset{\Delta, 48 \mathrm{~h}}{\stackrel{\mathrm{THF} / \mathrm{CH}_{3} \mathrm{CN}}{\longrightarrow}} \\
& \text { L } \\
& M=F e, R u, \text { or Os }
\end{aligned}
$$

Scheme 9
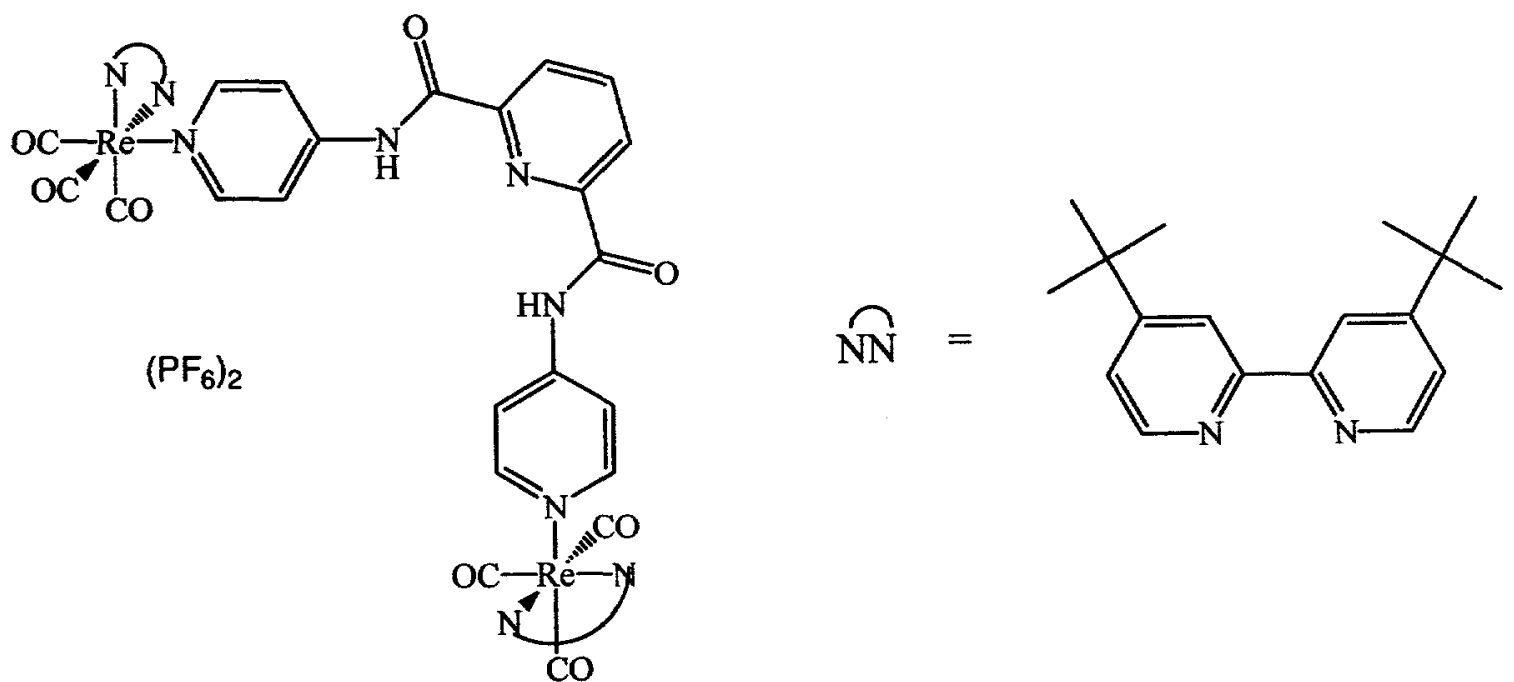

\section{References}

1. Lees, A. J. Anal. Chem. 1996, 68, 226 
2: (a) Drolet, D. P.; Lees, A. J. J. Am. Chem. Soc. 1990, 112, 5878. (b) Drolet, D. P.; Lees, A. J. J. Am. Chem. Soc. 1992, 114,4186 . (c) Purwoko, A. A; Lees, A. J. Coord. Chem. Revs. 1994, 132, 155. (d) Purwoko, A. A.; Drolet, D. P.; Lees, A. J. J. Organomet. Chem. 1995, 504, 107 . (e) Dunwoody, N.; Lees, A. J. Organometallics 1997, 16, 5770. (f) Lees, A. J. J. Organomet. Chem. 1998, 554, 1.

3. (a) Purwoko, A. A.; Lees, A. J. Inorg. Chem. 1995, 34, 424. (b) Purwoko, A. A; Lees, A. J. Inorg. Chem. 1996, 35, 675. (c) Purwoko, A. A.; Tibensky, S. D.; Lees, A. J. Inorg. Chem. 1996, 35, 7049.

4. (a) Belt, S. T.; Haddleton, D. M.; Perutz, R. N.; Smith, B. P. H.; Dixon, A. J. J. Chem. Soc., Chem. Commun. 1987, 1347. (b) Belt, S. T.; Grevels, F.-W.; Koltzbücher, W. E.; McCamley, A.; Perutz, R. N. J. Am. Chem. Soc. 1989, 111, 8373. (c) Grubbs, W. T.; Dougherty, T. P.; Heilweil, E. J. Chem. Phys. Letts. 1994, 227, 480. (d) Dougherty, T. P.; Grubbs, W. T.; Heilweil, E. J. J. Phys. Chem. 1994, 98, 9396. (e) Bromberg, S. E.; Lian, T.; Bergman, R. G.; Harris, C. B. J. Am. Chem. Soc. 1996, 118, 2069.

5. (a) Haddleton, D. M.; Perutz, R. N.; Jackson, S. A.; Upmacis, R. K.; Poliakoff, M. J. Organomet. Chem. 1986, 311, C15. (b) Sponsler, M. B.; Weiller, B. H.; Stoutland, P. O.; Bergman, R. G. J. Am. Chem. Soc. 1989, 111, 6841. (c) Weiller, B. H.; Wasserman, E. P.; Bergman, R. G.; Moore, C. B.; Pimentel, G. C. J. Am. Chem. Soc. 1989, 111, 8288. (d) Weiller, B. H.; Wasserman, E. P.; Moore, C. B.; Bergman, R. G.; J. Am. Chem. Soc. 1993, 115, 4326.

6. Hall, C.; Perutz, R. N. Chem. Rev. 1996, 96, 3125.

7. O'Connor, J. M.; Casey, C. P. Chem. Rev. 1987, 87, 307.

8. (a) Cramer, R.; Seilwell, L. P. J. Organomet. Chem. 1975, 92, 245. (b) Rerek, M. E.; Basolo, F. Organometallics 1983, 2, 372. (c) Rerek, M. E.; Basolo, F. J. Am. Chem. Soc. 1984, 106, 5908. (d) Ji, L.; Rerek, M. E.; Basolo, F. Organometallics, 1984, 3, 740. (e) Cheong, M.; Basolo, F. Organometallics, 1988, 7, 2041.

9. (a) Bonneau, R.; Kelly, J. M. J. Am. Chem. Soc. 1980, 102, 1220. (b) Lees, A. J.; Adamson, A. W. Inorg. Chem. 1981, 20, 4381. (c) Kelly, J. M.; Long, C.; Bonneau, R. J. Phys. Chem. 1983, 87, 3344. (d) Simon, J. D.; Xie, X. J. Phys. Chem. 1986, 90, 6751. (e) Simon, J. D.; Xie, X. J. Phys. Chem. 1987, 91, 5538. (f) Simon, J. D.; Xie, X. J. Phys. Chem. 1989, 93, 291. (g) Wang, L.; Zhu, X.; Spears, K. G. J. Am. Chem. Soc. 1988, 110, 8695. (h) Joly, A. G.; Nelson, K. A. J. Phys. Chem. 1989, 93, 2876. (i) Lee, M.; Harris, C. B. J. Am. Chem. Soc. 1989, 111, 8963.

10. (a) Xie, X.; Simon, J. D. J. Am. Chem. Soc. 1990, 112, 1130. (b) Yu, S.-C.; Xu, X.; Lingle, R.; Hopkins, J. B. J. Am. Chem. Soc. 1990, 112, 3668 . (c) O'Driscoll, E.; Simon, J. D. J. Am. Chem. Soc. 1990, 112, 6580. (d) Joly, A. G.; Nelson, K. A. Chem. Phys. 1991, 152, 69. (e) Dougherty, T. P.; Heilweil, E. J. J. Chem. Phys. 1994, 100, 4006. (f) Dougherty, T. P.; Heilweil, E. J. Chem. Phys. Letts. 1994, 227, 19. (g) Arrivo, S. M.; Dougherty, T. P.; Grubbs, W. T.; Heilweil, E. J. Chem. Phys. Letts. 1995, 235, 247. (h) Lian, T.; Bromberg, S. E.; Yang, H.; Proulx, G.; Bergman, R. G.; Harris, C. B. J. Am. Chem. Soc. 1996, 118, 3769. (i) Arnold, C. J.; Ye, T.-Q.; Perutz, R. N.; Hester, R. E.; Moore, J. N. Chem. Phys. Letts. 1996, 248, 464. (j) Wilms, M. P.; Baerends, E. J.; Rosa, A.; Stufkens, D. J. Inorg. Chem. 1997, $36,1541$.

11. Lees, A. J. Chem. Rev. 1987, 87, 711, and references therein. 
12. Ghosh, C. K.; Graham, W. A. G. J. Am. Chem. Soc. 1987, 109, 4726.

13. Dunwoody, N.; Sun, S.-S.; Lees, A. J. Inorg. Chem., submitted for publication.

14. Gallop, M.; Johnson, B. F. G.; Lewis, J.; McCamley, A.; Perutz, R. N. J. Chem. Soc., Chem. Commun. 1988, 1071.

15. Ainscough, E. W.; Brodie, A. M.; Coll, R. M.; Kotch, T. G.; Lees, A. J.; Mair, A. J.; Waters, J. M. J. Organomet. Chem., 1996, 517, 173.

16. (a) Charalambous, E.; Gade, L. H.; Johnson, B. F. G.; Kotch, T. G.; Lees, A. J.; Lewis, J.; McPartlin, M. Angew. Chem., Int. Ed. Engl. 1990, 29, 1137. (b) Gade, L. H.; Johnson, B. F. G.; Lewis, J.; Charalambous, E. McPartlin, M.; Kotch, T. G.; Lees, A. J. J. Am. Chem. Soc. 1991, 113, 8698.

17. Rawlins, K. A.; Lees, A. J.; Fuerniss, S. J.; Papathomas, K. I. Chem. Mater. 1996, 8, 1540.

18. (a) Grant, J. T.; Dunwoody, N.; Jakúbek, V.; Lees, A. J. Poly. Prepr. (Am. Chem. Soc., Div. Polym. Chem.) 1998, 39 (2), 687. (b) Grant, J. T.; Dunwoody, N.; Jakúbek, V.; Lees, A. J. Polym. Polym. Compos. 1998, 6, 47.

19. (a) Lees, A. J. Comments Inorg. Chem. 1995, 17, 319. (b) Lees, A. J. Coord. Chem. Revs. 1998, 177, 3. (c) Lees, A. J. Polym. Polym. Compas. 1998, 6, 121. (d) Lees, A. J. in Sensors and Optical Switching Phenomena, Ramamurthy, V.; Schanze, K. S., Eds., Molecular and Supramolecular Photochemistry Series, Vol. 6, Marcel Dekker, New York, 2000, in press.

20. Panesar, R. S.; Dunwoody, N.; Lees, A. J. Inorg. Chem. 1998, 37, 1648.

21. Borja, C. E.; Jakúbek, V.; Lees, A. J. Inorg. Chem. 1998, 37, 2281.

22. (a) Jakúbek, V.; Lees, A. J.; Fuerniss, S. J.; Papathomas, K. I. Poly. Prepr. (Am. Chem. Soc., Div. Polym. Chem.) 1997, 38 (1), 195. (b) Jakúbek, V.; Lees, A. J. Chem. Commun. 1999, 1631. (c) Jakúbek, V.; Lees, A. J. Inorg. Chem., submitted for publication.

23. Sun, S.-S.; Robson, E.; Dunwoody, N.; Silva, A. S.; Brinn, I. M.; Lees, A. J. Chem. Commun. 2000, 201.

24. Sun, S.-S.; Lees, A. J. Inorg. Chem. 1999, 38, 4181.

25. Sun, S.-S.; Silva, A. S.; Brinn, I. M.; Lees, A. J. Inorg. Chem. 2000, 39, 1344.

26. Sun, S.-S.; Lees, A. J. J. Am. Chem. Soc., submitted for publication.

27. Sun, S.-S.; Lees, A. J. Chem. Commun., submitted for publication.

\section{E. Major Research Accomplishments and their Significance}

We have provided the first quantitative photochemical measurements for a number of important $\mathrm{C}-\mathrm{H}$ bond activation processes. This has involved a determination of the effectiveness of photochemical $\mathrm{C}-\mathrm{H}$ activation at several excitation wavelengths in each system and also for different hydrocarbon substrates. Arising from these measurements is fundamental knowledge concerning the photochemical mechanism, including information on the nature of the electronically-excited states and primary photoproducts formed upon light excitation. An understanding of the photophysical processes and their influence on the $\mathrm{C}-\mathrm{H}$ bond activation reactivity is also emerging for several systems. This quantitative photochemical information is essential in elucidating reaction mechanisms and supporting other measurements using time-resolved and low temperature techniques. 
F. Publications Arising from this Project

1. "Photophysical Properties of $\mathrm{CpRe}(\mathrm{CO})_{2} \mathrm{~L}$ Complexes. Distinct Orbital Emissions from Nonequilibrated Excited States in Room-Temperature Solution," Marsha M. Glezen and Alistair J. Lees, J. Am. Chem. Soc. 1989, 111, 6602-6610.

2. "Photochemistry of $\left(\eta^{5}-\mathrm{C}_{5} \mathrm{H}_{5}\right) \mathrm{Rh}(\mathrm{CO})_{2}$ in Phosphine Solutions: Evidence for an Associative Photosubstitution Mechanism," Denis P. Drolet and Alistair J. Lees, $J$. Am. Chem. Soc. 1990, 112, 5878-5879.

3. "The Time-Resolved Infrared Spectrum of the MLCT Excited State of W(CO)5(4CNpyr) (4-CNpyr = Cyanopyridine): Photophysics and Photochemistry," Paul Glyn, Frank P. A. Johnson, Michael W. George, Alistair J. Lees and James J. Turner, Inorg. Chem. 1991, 30, 3543-3546.

4. "Photochemical Core Manipulations in High Nuclearity Os-Hg Clusters," Lutz H. Gade, Brian F. G. Johnson, Jack Lewis, Eleni Charalambous, Mary McPartlin, Thomas Kotch and Alistair J. Lees, J. Am. Chem. Soc. 1991, 113, 8698-8704.

5. "Solution Photochemistry of $\left(\eta^{5}-\mathrm{C}_{5} \mathrm{R}_{5}\right) \mathrm{Rh}(\mathrm{CO})_{2}(\mathrm{R}=\mathrm{H}, \mathrm{Me})$ Complexes: Pathways for Photosubstitution and C-H/Si-H Bond Activation Reactions," Denis P. Drolet and Alistair J. Lees, J. Am. Chem. Soc. 1992, 114, 4186-4194.

6. "Multiple-State Emission and Excited-State Dynamics of $\mathrm{CpRe}(\mathrm{CO})_{2} \mathrm{~L}(\mathrm{~L}=3-$ Benzoylpyridine and 4-Benzoylpyridine) Complexes in Fluid and Glassy Solutions," Zhikai Wang and Alistair J. Lees, Inorg. Chem. 1993, 32, 1493-1501.

7. "Photochemical Mechanisms in Intermolecular C-H Bond Activation Reactions of Organometallic Complexes," Alistair J. Lees and Agus A. Purwoko, Coord. Chem. Revs. 1994, 132, 155-160.

8. "Photochemistry and C-H Bond Activation Reactivity of $\left(\mathrm{HBPz}_{3}^{*}\right) \mathrm{Rh}(\mathrm{CO})_{2}\left(\mathrm{Pz}^{*}\right.$ = 3,5-Dimethylpyrazolyl) in Hydrocarbon Solution," Agus A. Purwoko and Alistair J. Lees, Inorg. Chem. 1995, 34, 424-425.

9. "Photophysical Aspects of C-H Bond Activation in Rhodium Dicarbonyl Complexes," Agus A. Purwoko, Denis P. Drolet and Alistair J. Lees, J. Organomet. Chem. 1995, 504, 107-113.

10. "The Luminescence Rigidochromic Effect Exhibited by Organometallic Complexes: Rationale and Applications," Alistair J. Lees, Comments Inorg. Chem. 1995, 17, 319-346.

11. "Photochemical C-H Bond Activation Reactivity of $\left(\mathrm{HBPz}_{3}\right) \mathrm{Rh}(\mathrm{CO})_{2}\left(\mathrm{Pz}^{\prime}=3,5-\right.$ Dimethylpyrazolyl) in Alkane Solutions," Agus A. Purwoko and Alistair J. Lees, Inorg. Chem. 1996, 35, 675-682. 
12. "A Photochemical Procedure for Determining Reaction Quantum Efficiencies in Systems with Multi Component Inner Filter Absorbances" Alistair J. Lees, Anal. Chem. 1996, 68, 226-229.

13. "Luminescence of $\mathrm{W}(\mathrm{CO})_{4}$ (4-Me-phen) in Photosensitive Thin Films: A Molecular Probe of Acrylate Polymerization," Kathleen A. Rawlins, Alistair J. Lees, Stephen J. Fuerniss and Kostas I. Papathomas, Chem. Mater. 1996, 8, 1540-1544.

14. "The Photochemical Reactivity of Triosmium Cluster Complexes Containing 2Mercaptopyridine Ligands: The Crystal and Molecular Structures of the Linked Clusters $\left[\left\{\mathrm{Os}_{3} \mathrm{H}(\mathrm{CO})_{10}\right\}_{2}\left(\mu-\mathrm{SC}_{5} \mathrm{H}_{3} \mathrm{NCO}_{2}\right)\right]$ and $\left[\left\{\mathrm{Os}_{3} \mathrm{H}(\mathrm{CO})_{9}\right\}(\mu-\right.$ $\left.\left.\left.\mathrm{SC}_{5} \mathrm{H}_{3} \mathrm{NCO}_{2}\right) \quad \mathrm{O}_{3} \mathrm{H}(\mathrm{CO})_{10}\right\}\right]$," Eric W. Ainscough, Andrew M. Brodie, Richard K. Coll, Thomas G. Kotch, Alistair J. Lees, Angelika J. A. Mair and Joyce M. Waters, J. Organomet. Chem. 1996, 517, 173-181.

15. "Substrate and Solvent Influence on the Photochemical C-H Bond Activation Reactivity of $\left(\mathrm{HBPz}^{\prime}{ }_{3}\right) \mathrm{Rh}(\mathrm{CO})_{2}$ ( $\mathrm{Pz}^{\prime}=$ 3,5-Dimethylpyrazolyl)," Agus A. Purwoko, Stephen J. Tibensky and Alistair J. Lees, Inorg. Chem. 1996, 35, 70497055.

16. "Photocatalytic and Photoinitiating Properties of Iron Organometallic Complexes in Solution and Aromatic Dicyanate Esters," Vladimír Jakúbek, Alistair J. Lees, Stephen J. Fuerniss and Kostas I. Papathomas, Polym. Prepr. (Am. Chem. Soc., Div. Polym. Chem.) 1997, 38(1), 195-196.

17. "Quantitative Measurements of $\mathrm{CpRh}(\mathrm{CO})_{2}\left(\mathrm{Cp}=\eta^{5}-\mathrm{C}_{5} \mathrm{H}_{5}\right)$ Photochemistry in Various Hydrocarbon Solution: Mechanisms for Ligand Photosubstitution and Intermolecular C-H and Si-H Bond Activation Reactions," Nicholas Dunwoody and Alistair J. Lees, Organometallics 1997, 16, 5770-5778.

18. "Photochemical Features of Intermolecular C-H Bond Activation," Alistair J. Lees, J. Organomet. Chem. 1998, 554, 1-11.

19. "Organometallic Complexes as Luminescence Probes in Monitoring Thermal and Photochemical Polymerizations," Alistair J. Lees, Coord. Chem. Revs. 1998, 177, 3-35.

20. "Wavelength-Dependent Photochemistry of W(CO $)_{4}(\mathrm{en})$ (en = ethylenediamine): Evidence for Distinct Chemical Reactivities from Singlet and Triplet Ligand Field Excited States," Rahul S. Panesar, Nicholas Dunwoody and Alistair J. Lees, Inorg. Chem. 1998, 37, 1648-1650. 
21. "Photoluminescent Organometallic Complexes as Spectroscopic Probes of Aromatic Cyanate Ester Polymerization," Jewel T. Grant, Nicholas Dunwoody, Vladimír Jakúbek and Alistair J. Lees, Polym. Polym. Compos. 1998, 6, 47-50.

22. "Quantitative Photochemistry of $\left(\eta^{5}-\mathrm{C}_{5} \mathrm{H}_{5}\right) \mathrm{Fe}(\mathrm{CO})_{2} \mathrm{I}$ in Solution: Effective Heterolytic Fe-I Dissociation upon Long-Wavelength Excitation," Charlene E. Borja, Vladimír Jakúbek and Alistair J. Lees, Inorg. Chem. 1998, 37, 2281-2284.

23. "New Phosphorescence Probes for Monitoring the Kinetics of Thermal and Photochemical Polymerization," Alistair J. Lees, Polym. Polym. Compos. 1998, 6, 121-131.

24. "Organometallic Luminescence Probes in Aromatic Cyanate Ester Polymerization," Jewel T. Grant, Nicholas Dunwoody, Vladimír Jakúbek and Alistair J. Lees, Polym. Prepr. (Am. Chem. Soc., Div. Polym. Chem.) 1998, 39 (2), 687-688.

25. "Wavelength Dependent Photochemistry of an Iron-Arene Organometallic Photoinitiator: a Quantitative Study of the Photoreactivity," Vladimír Jakúbek and Alistair J. Lees, Chem. Commun. 1999, 1631-1632.

26. "New Self-Assembly Luminescent Molecular Triangle and Square Rhenium (I) Complexes," Shih-Sheng Sun and Alistair J. Lees, Inorg. Chem. 1999, 38, 41814182 .

27. "Quantitative Photochemistry of Organometallic Complexes: Insight to their Photophysical and Photoreactivity Mechanisms," Alistair J. Lees, Coord. Chem. Revs. 2000, in press.

28. "Photoswitchable Trinuclear Transition-Metal Complexes. Intramolecular TripletTriplet Energy Transfer from fac-(diimine)Re $\mathrm{I}^{\mathrm{I}}(\mathrm{CO})_{3}$ Chromophores to a Stilbenelike Bridging Ligand," Shih-Sheng Sun, Elizabeth Robson, Nicholas Dunwoody, Alexsandra S. Silva, Ira M. Brinn and Alistair J. Lees, Chem. Commun. 2000, 201202.

29. "Self-Assembly Molecular Squares with Metal Complexes as Bridging Ligands," Shih-Sheng Sun, Alexsandra S. Silva, Ira M. Brinn and Alistair J. Lees, Inorg. Chem. 2000, 39, 1344-1345.

30. "Luminescent Metal Complexes as Spectroscopic Probes of Monomer/Polymer Environments," Alistair J. Lees, in Sensors and Optical Switching Phenomena, V. Ramamurthy and Kirk S. Schanze, Eds., Molecular and Supramolecular Photochemistry Series, Vol. 6, Marcel Dekker, New York, 2000, in press.

31. "Quantitative Photochemistry and Mechanisms for a Series of Rhodium Dicarbonyl Derivatives," Nicholas Dunwoody, Shih-Sheng Sun and Alistair J. Lees, Inorg. Chem., submitted for publication. 
32. "Self-Assembly Triangular and Square Rhenium(I) Tricarbonyl Complexes: A Comprehensive Study of their Preparation, Electrochemistry, Photophysics, Photochemistry and Host-Guest Properties," Shih-Sheng Sun and Alistair J. Lees, J. Am. Chem. Soc., submitted for publication.

33. "Quantitative Wavelength Dependent Photochemistry of the $\left[\mathrm{CpFe}\left(\eta^{6}-\mathrm{ipb}\right)\right] \mathrm{PF}_{6}$ (ipb = isopropylbenzene) Photoinitiator," Vladimír Jakúbek and Alistair J. Lees, Inorg. Chem., submitted for publication.

34. "Anion Recognition through Hydrogen Bonding: A Simple, Yet Highly Sensitive, Luminescent Metal-Complex Receptor," Shih-Sheng Sun and Alistair J. Lees, Chem. Commun., submitted for publication.

G. Conference Presentations Arising from this Project

1. "Photophysical Properties of $\mathrm{M}(\mathrm{CO})_{4}$ (a,a'-diimine) ( $\mathrm{M}=\mathrm{Mo}$, W) Complexes," Kathleen A. Rawlins and Alistair J. Lees, 198th ACS National Meeting, Miami, Florida, USA, 1989.

2. "Photochemistry of $\left(\eta^{5}-\mathrm{C}_{5} \mathrm{R}_{5}\right) \operatorname{Ir}(\mathrm{CO})_{2}\left(\mathrm{R}=\mathrm{H}, \mathrm{CH}_{3}\right)$ and $\left(\eta^{5}-\mathrm{C}_{9} \mathrm{H}_{7}\right) \operatorname{Ir}(\mathrm{CO})_{2}$ in Dilute Hydrocarbon Solutions," Denis P. Drolet and Alistair J. Lees, 199th ACS National Meeting, Boston, Massachusetts, USA, 1990.

3. "Photochemistry of Large Osmium Clusters: Visible Laser Excitation of $[\mathrm{PPN}]_{2}\left[\mathrm{Os}_{18} \mathrm{Hg}_{3} \mathrm{C}_{2}-(\mathrm{CO})_{42}\right]$ and its Corresponding Radical Anion Complex," Thomas Kotch, Alistair J. Lees, Lutz Gade, Brian F. G. Johnson and Jack Lewis, 199th ACS National Meeting, Boston, Massachusetts, USA, 1990.

4. "Organometallic Compounds as Luminescent Probes and Photoinitiators in Thin Film Photoresists," Kathleen A. Rawlins, Alistair J. Lees, Stephen J. Fuerniss and Kostas I. Papathomas, 199th ACS National Meeting, Boston, Massachusetts, USA, 1990.

5. "Photochemistry of $\left(\eta^{5}-\mathrm{C}_{5} \mathrm{H}_{5}\right) \mathrm{Rh}(\mathrm{CO})_{2}$ in Phosphine Solutions: Evidence for an Associative Photosubstitution Mechanism," Alistair J. Lees and Denis P. Drolet, Florida Catalysis Conference, Palm Coast, Florida, USA, 1990.

6. "Photophysical Deactivation of $\mathrm{W}(\mathrm{CO})_{5}$ (4-cyanopyridine) in Fluid and Glassy Solutions," Alistair J. Lees and Kathleen M. Rawlins, Fifth International Conference on Mechanisms of Reactions in Solution, Canterbury, UK, 1990.

7. "Kinetic Analysis of the Excited-State Deactivation Mechanisms in $\mathrm{CpRe}(\mathrm{CO})_{2} \mathrm{~L}$ Complexes," Alistair J. Lees and Marsha M. Glezen, Fifth International Conference on Mechanisms of Reactions in Solution, Canterbury, UK, 1990. 
8. "Photochemistry of Large Osmium Clusters: Visible Laser Excitation of $\left[\mathrm{PPN}_{2}\left[\mathrm{Os}_{18} \mathrm{Hg}_{3} \mathrm{C}_{2}-(\mathrm{CO})_{42}\right]\right.$ and its Corresponding Radical Anion Complex," Alistair J. Lees, Thomas Kotch, Lutz Gade, Brian F. G. Johnson and Lord Jack Lewis, XIIIth IUPAC Symposium on Photochemistry, Warwick, UK, 1990.

9. "Photochemistry of $\left(\eta^{5}-\mathrm{C}_{5} \mathrm{R}_{5}\right) \operatorname{Ir}(\mathrm{CO})_{2}\left(\mathrm{R}=\mathrm{H}, \mathrm{CH}_{3}\right)$ and $\left(\eta^{5}-\mathrm{C}_{9} \mathrm{H}_{7}\right) \operatorname{Ir}(\mathrm{CO})_{2}$ in Dilute Hydrocarbon Solutions," Alistair J. Lees and Denis P. Drolet, XIIIth IUPAC Symposium on Photochemistry, Warwick, UK, 1990.

10. "Organometallic Compounds as Luminescent Probes in Thin Film Photoresists," Alistair J. Lees, Kathleen A. Rawlins, Stephen J. Fuerniss and K. I. Papathomas, XIIIth IUPAC Symposium on Photochemistry, Warwick, UK, 1990.

11. "Phosphorescent Organometallic Compounds as Spectroscopic Probes in Polymers," Thomas G. Kotch, Alistair J. Lees, Stephen J. Fuerniss and Kostas I. Papathomas, 201st ACS National Meeting, Atlanta, Georgia, USA, 1991.

12. "Photophysical Properties of $\mathrm{CpRe}(\mathrm{CO})_{2} \mathrm{~L}(\mathrm{~L}=3$-Benzoylpyridine and 4Benzoylpyridine) Complexes," Zhikai Wang and Alistair J. Lees, 201st ACS National Meeting, Atlanta, Georgia, USA, 1991.

13. "Luminescent Eight-Coordinate Chelates of Tungsten(IV) and Molybdenum(IV)," Adrian A. White, Ronald D. Archer, Zhikai Wang and Alistair J. Lees, 21st ACS Northeast Regional Meeting, Amherst, Massachusetts, USA, 1991.

14. "Photochemistry of Metal Carbonyl Complexes that Facilitate Intermolecular C-H Bond Activation," Alistair J. Lees, 3rd DOE/BES Organometallic Chemistry and Homogeneous Catalysis Research Conference, Madison, Wisconsin, USA, 1991.

15. "Temperature Effects on the Lowest Energy Excited States of Binuclear Organometallic Tungsten Complexes," M. M. Zulu and A. J. Lees, XXVII Colloquium Spectroscopicium Internationale, Bergen, Norway, 1991.

16. "Organometallic Complexes as Luminescent Probes in the Cure Monitoring of Thermal and Photosensitive Polymers," Alistair J. Lees, Thomas G. Kotch, Stephen J. Fuerniss, Kostas I. Papathomas and Randy Snyder, Ninth International Symposium on the Photochemistry and Photophysics of Coordination Compounds, Fribourg, Switzerland, 1991.

17. "Thiourea-Triosmium Cluster Compounds - Structural, Spectroscopic and Photochemical Studies," E. W. Ainscough, A. M. Brodie, S. L. Ingham, J. M. Walters, J. Lewis, A. J. Lees, and T. G. Kotch, Royal Society of Chemistry Dalton Division Symposium on the Chemistry of the Early Transition Metals, Brighton, UK, 1991. 
18. "Monitoring the Cure of Photosensitive Polymers Using a Luminescent Rhenium Carbonyl Complex as a Spectroscopic Probe," Thomas G. Kotch, Alistair J. Lees, Stephen J. Fuerniss, Kostas I. Papathomas and Randy Snyder, 202nd ACS National Meeting, New York, New York, USA, 1991.

19. "What is the Origin of the Luminescence Rigidochromic Effect?" Thomas G. Kotch and Alistair J. Lees, 203rd ACS National Meeting, San Francisco, California, USA, 1992.

20. "Photochemistry of $\mathrm{HB}\left(\mathrm{Pz}^{*}{ }_{3}\right) \mathrm{Rh}(\mathrm{CO})_{2}\left(\mathrm{Pz}^{*}=3,5\right.$-dimethylpyrazol-1-yl) in Hydrocarbon Solution: Quantum Yields for Intermolecular C-H Bond Activation," Agus A. Purwoko and Alistair J. Lees, 203rd ACS National Meeting, San Francisco, California, USA, 1992.

21. "Pathways for Photosubstitution and $\mathrm{C}-\mathrm{H} / \mathrm{Si}-\mathrm{H}$ Bond Activation in $\mathrm{CpRh}(\mathrm{CO})_{2}$ and $\mathrm{Cp} * \mathrm{Rh}(\mathrm{CO})_{2}$," Alistair J. Lees and Denis P. Drolet, 203rd ACS National Meeting, San Francisco, California, USA, 1992.

22. "Organometallic Complexes as Photocatalysts in the Polycyclotrimerization Reaction of Aromatic Dicyanates," Thomas G. Kotch, Alistair J. Lees, Stephen J. Fuerniss and Kostas I. Papathomas, 203rd ACS National Meeting, San Francisco, California, USA, 1992.

23. "Photochemistry of Intermolecular C-H Bond Activation Reactions,"Alistair J. Lees, U. S. Department of Energy Review of Basic Energy Sciences Catalysis Research Program, Bethesda, Maryland, USA, 1992.

24. "Photochemistry of $\mathrm{CpRh}(\mathrm{CO})_{2}$ in Hydrocarbon Solutions: A Mechanism for Si$\mathrm{H}$ and C-H Activation," Alistair J. Lees and Agus A. Purwoko, RIKEN International Symposium on New Trends in Photochemistry of Coordination Compounds, Wako-shi, Saitama, Japan, 1993.

25. "Luminescent Organometallic Complexes as Visible Probes in Monitoring Polymerization of Epoxy Resins and Photosensitive Thin Films," Alistair J. Lees, Tenth International Symposium on the Photochemistry and Photophysics of Coordination Compounds, Sendai, Japan, 1993.

26. "Photochemical Mechanisms in Intermolecular C-H Bond Activation Reactions of Organometallic Complexes," Alistair J. Lees and Agus A. Purwoko, Tenth International Symposium on the Photochemistry and Photophysics of Coordination Compounds, Sendai, Japan, 1993.

27. "Photochemistry and Unusually Efficient C-H Bond Activation Chemistry of $\left(\mathrm{HBPz}_{3}\right)_{\mathrm{Rh}}(\mathrm{CO})_{2}$ in Hydrocarbon Solution," Alistair J. Lees and Agus A. Purwoko, XVth IUPAC Symposium on Photochemistry, Prague, Czech Republic, 1994. 
28. "Photophysical and Photochemical Properties of Metal Carbonyl Complexes," Alistair J. Lees, New Zealand Institute of Chemistry, Inorganic and Organometallic Chemistry Specialist Group Meeting, Palmerston North, New Zealand, 1995.

29. "Solution Photochemistry of $\left(\mathrm{HBPz}^{*} 3\right) \mathrm{Rh}(\mathrm{CO})_{2}$ : Highly Effective $\mathrm{C}-\mathrm{H}$ Bond Activation of Hydrocarbons," Alistair J. Lees and Agus A. Purwoko, New Zealand Institute of Chemistry, Inorganic and Organometallic Chemistry Specialist Group Meeting, Palmerston North, New Zealand, 1995.

30. "Emission Spectroscopy and Cyclic Voltammetry of Tungsten(IV) EightCoordinate-Chelate Complexes Containing Bidentate Picolinato Ligands," Adrian White, Ronald D. Archer, Zhikai Wang and Alistair J. Lees, 209th ACS National Meeting, Anaheim, California, USA, 1995.

31. "Photophysical Studies of Kodak Thin Film Resist," Kathleen A. Rawlins, Alistair J. Lees, Stephen J. Fuerniss and Kostas I. Papathomas, 211th ACS National Meeting, New Orleans, Louisiana, USA, 1996.

32. "A Tungsten Organometallic Complex as a Spectroscopic Probe of Acrylate Polymerization in Thin Films," Kathleen A. Rawlins, Alistair J. Lees, Stephen J. Fuerniss and Kostas I. Papathomas, 211th ACS National Meeting, New Orleans, Louisiana, USA, 1996.

33. "Photochemical Reactivity and $\mathrm{C}-\mathrm{H}$ Bond Activation Efficiency of $\left(\mathrm{HBPz}_{3}{ }_{3}\right) \mathrm{Rh}(\mathrm{CO})_{2}\left(\mathrm{Pz}^{\prime}=3,5\right.$-Dimethylpyrazolyl) with Various Hydrocarbon Substrates," Agus A. Purwoko, Stephen D. Tibensky and Alistair J. Lees, 211th ACS National Meeting, New Orleans, Louisiana, USA, 1996.

34. "Photochemical C-H Bond Activation Reactivity of $\left(\mathrm{HBPz}^{3}\right) \mathrm{Rh}(\mathrm{CO})_{2}\left(\mathrm{Pz}^{\prime}=3,5-\right.$ Dimethylpyrazolyl)," Agus A. Purwoko, Stephen D. Tibensky and Alistair J. Lees, Eighth Inter-American Photochemical Society Conference, Foz do Iguaçú, Brazil, 1996.

35. "Photocatalytic and Photoinitiating Properties of Iron Organometallic Complexes in Solution and Aromatic Dicyanate Esters," Vladimír Jakúbek, Alistair J. Lees, Stephen J. Fuerniss and Kostas I. Papathomas, 213th ACS National Meeting, San Francisco, California, USA, 1997.

36. "Photochemical C-H/Si-H Activation and Photosubstitution Reactivity of $\mathrm{CpRh}(\mathrm{CO})_{2}\left(\mathrm{Cp}=\eta^{5}-\mathrm{C}_{5} \mathrm{H}_{5}\right)$ in Fluid Solution," Nicholas Dunwoody and Alistair J. Lees, 213th ACS National Meeting, San Francisco, California, USA, 1997. 
37. "Cyclopentadienyliron(II) Arene Complexes as Photocatalysts and Photoinitiators in Solution and Aromatic Dicyanate Esters," Vladimír Jakúbek, Alistair J. Lees, Stephen J. Fuerniss and Kostas I. Papathomas, 12th International Symposium on the Photochemistry and Photophysics of Coordination Compounds, St. Michaels College, Vermont, USA, 1997.

38. "Photochemical $\mathrm{C}-\mathrm{H} / \mathrm{Si}-\mathrm{H}$ Activation and Photosubstitution Reactivity of $\mathrm{CpRh}(\mathrm{CO})_{2}\left(\mathrm{Cp}=\eta^{5}-\mathrm{C}_{5} \mathrm{H}_{5}\right)$ in Fluid Solution," Nicholas Dunwoody and Alistair J. Lees, 12th International Symposium on the Photochemistry and Photophysics of Coordination Compounds, St. Michaels College, Vermont, USA, 1997.

39. "Photochemistry of Intermolecular C-H Bond Activation Reactions," Alistair J. Lees, 4th DOE/BES Homogeneous Catalysis and Organometallic Chemistry Conference, Baltimore, Maryland, 1998.

40. "Wavelength and Solvent Dependent Photochemistry of an Iron-Arene Organometallic Photoinitiator Complex, $\left[\mathrm{CpFe}\left(\eta^{6}\right.\right.$-isopropylbenzene $\left.)\right] \mathrm{PF}_{6}, "$ Vladimír Jakúbek and Alistair J. Lees, 216th ACS National Meeting, Boston, Massachusetts, 1998.

41. "Synthesis and Characterization of Self-Assembly Luminescent Square Rhenium(I) Complex," Shih-Sheng Sun and Alistair J. Lees, 216th ACS National Meeting, Boston, Massachusetts, 1998.

42. "Quantitative Photochemical Studies of ( $\eta^{5}$-Ligand)Rhodium Dicarbonyl Species in Hydrocarbon Solutions," Nicholas Dunwoody and Alistair J. Lees, 216th ACS National Meeting, Boston, Massachusetts, 1998.

43. "Organometallic Luminescence Probes in Aromatic Cyanate Ester Polymerization," Jewel T. Grant, Nicholas Dunwoody, Vladimír Jakúbek and Alistair J. Lees, 216th ACS National Meeting, Boston, Massachusetts, 1998.

44. "Quantitative Photochemistry of Organometallic Complexes: Insight to their Photophysical and Photoreactivity Mechanisms," Alistair J. Lees, 217th ACS National Meeting, Anaheim, California, 1999 (in honor of Arthur W. Adamson's 80th birthday).

45. "Halide and $\mathrm{pH}$ Dependence of the Ground and Excited States of a Series of Rhenium(I) Tricarbonyl Diimine Compounds," Alexsandra S. Silva, Ka-Kiu Cheung, Shih-Sheng Sun, Nicholas Dunwoody, Ira M. Brinn and Alistair J. Lees, 219th ACS National Meeting, San Francisco, California, 2000. 
46. "Photoswitchable Polynuclear Transition-Metal Complexes: Intramolecular Triplet-Triplet Energy Transfer from fac-(diimine) $\operatorname{Re}^{\mathrm{I}}(\mathrm{CO})_{3}$ Chromophores to a Stilbene-like Bridging Ligand," Shih-Sheng Sun, Elizabeth Robson, Nicholas Dunwoody, Alexsandra S. Silva, Ira M. Brinn and Alistair J. Lees, 219th ACS National Meeting, San Francisco, California, 2000.

47. "Self-Assembly Molecular Squares with Metal Complexes as Bridging Ligands and Their Binding Properties Towards Anions," Shih-Sheng Sun, Alexsandra S. Silva, Ira M. Brinn and Alistair J. Lees, 219th ACS National Meeting, San Francisco, California, 2000.

48. "Molecular Squares Assembled from 11 Components," Shih-Sheng Sun and Alistair J. Lees, 219th ACS National Meeting, San Francisco, California, 2000.

49. "Anion Recognition through Hydrogen Bonding: A Simple, Yet Highly Sensitive, Luminescent Metal-Complex Receptor," Shih-Sheng Sun and Alistair J. Lees, to be presented at the 220th ACS National Meeting, Washington, D.C., 2000.

H. Research Lectures Presented on this Project at the Following Institutions:

Adelphi University, USA

Albany University (SUNY), USA

Alcan International, Banbury, UK

(Univ.) Amsterdam, The Netherlands

(Univ.) Auckland, New Zealand

Australian National University, Australia

Binghamton University (SUNY), USA

Bristol University, UK

Brooklyn Polytechnic University, USA

(Univ.) Calgary, Canada

Cambridge University, UK

(Univ.) Canterbury, New Zealand

City University of New York, Queen's, USA

Colgate University, USA

Czech. Academy of Sciences, Prague, Czech Republic

Dickinson College, USA

Dublin City University, Eire

(Univ.) East Anglia, UK

East Stroudsburg University, USA

Exeter University, UK

Federal Universidade do Rio de Janeiro, Brazil

General Electric, Corporate Research and Development, USA

Geneseo University (SUNY), USA

George Washington University, USA

Hamilton College, USA

Hofstra University, USA 
Hull University, UK

IBM, Endicott, USA

Ithaca College, USA

King's College, Wilkes-Barre, USA

Leeds University, UK

Leicester University, UK

Lehigh University, USA

Lycoming College, USA

Manhattan College, USA

(Univ.) Maryland, Baltimore County, USA

(Univ.) Massachusetts at Amherst, USA

(Univ.) Newcastle-upon-Tyne, UK

(Univ.) New South Wales, Australia

Northeastern University, USA

Nottingham University, UK

Oneonta University (SUNY), USA

Oxford University, UK

Pace University, USA

Pittsburgh University, USA

Potsdam University (SUNY), USA

Queen Mary and Westfield College, University of London, UK

Queen's University, Kingston, Canada

Rensselaer Polytechnic Institute, USA

(Univ.) Rochester, USA

St. John Fisher College

St. Lawrence University, USA

Siena College, USA

Southampton University, UK

(Univ.) Southern California, USA

Stony Brook University (SUNY), USA

Stuttgart University, West Germany

SUNY College at Brockport, USA

Susquehanna University, USA

Syracuse University, USA

Union College, USA

Victoria University, New Zealand

(Univ.) Wales, Cardiff, UK

Waikato University, New Zealand

Wollongong University, Australia

York University, Ontario, Canada

(Univ.) York, UK 